\title{
Effects of processing methods (rolling vs. pelleting vs. steam-flaking) of cool-season adapted oats on dairy cattle production performance and metabolic characteristics compared with barley
}

Marcela R. Tosta, Luciana L. Prates, (1) David A. Christensen, and Peiqiang Yu* (1)

Department of Animal and Poultry Science, College of Agriculture and Bioresources, University of Saskatchewan, Saskatoon SK S7N 5B5, Canada

\section{ABSTRACT}

Several processing techniques can be used to slow the degradation rate in the rumen and thus provide more bypass crude protein $(\mathrm{CP})$ and starch to the small intestine. The aim of this study was to evaluate the effects of processing methods on cool-season adapted oat grain compared with dry-rolled barley grain, when fed as total mixed ration (TMR) for lactating dairy cows. Eight lactating Holstein cows were used in a replicated $4 \times 4$ Latin square design with 21 -d periods and fed TMR with 1 of 4 treatments: dry-rolled oats, steamflaked oats, pelleted oats, or dry-rolled barley. Dry matter intake (DMI) ranged from 28.19 to $31.61 \mathrm{~kg} / \mathrm{d}$ and was lower for rolled oats compared with pelleted oats. Despite the nutrient intake being higher for cows fed pelleted oats, those fed rolled oats had the highest milk production and milk fat percentage $(49.23 \mathrm{~kg} / \mathrm{d}$ and $4 \%$, respectively). Ruminal fermentation characteristics were similar across treatments, with only significant differences in concentrations of acetate (lowest for pelleted oats) and total short-chain fatty acids (highest value for rolled barley) and a lower $\mathrm{pH}$ for flaked oats at the 9-h and 12-h points. Dietary treatments did not affect total-tract digestibility of dry matter, organic matter, or CP; digestibility of starch was the lowest for rolled barley (89.04\%). Measured blood metabolites, urea, glucose, and $\beta$-hydroxybutyrate, were not affected by dietary treatment. Purine derivatives and microbial $\mathrm{N}$ supply were also unaffected by dietary treatments. Cows fed flaked oat-based TMR showed the lowest $\mathrm{N}$ excretion in milk; however, the lack of difference between diets with regard to urinary $\mathrm{N}$ and fecal $\mathrm{N}$ excretion resulted in no significant changes in $\mathrm{N}$ balance between diets. Therefore, rolled oats allow cows to have higher milk production with lower DMI compared with all other treatments in this study.

Received May 9, 2019.

Accepted August 14, 2019.

*Corresponding author: peiqiang.yu@usask.ca
Key words: cool-season adapted oat variety, dairy production, rolling, pelleting, steam-flaking

\section{INTRODUCTION}

Lactating dairy cows require a high energy intake to maintain milk production and drive microbial protein synthesis. Typically, dairy cows rations contain 40 to $50 \%$ of concentrates, which are used to supply starch as an energy source. In western Canada, barley grain is widely used as a concentrate in dairy farms; however, the prairies region of Canada is responsible for producing more than $90 \%$ of oats in the country (Statistics Canada, 2018), and with a lower price per bush compared with barley grain, oats became a cost-effective source of digestible energy. Although oat grain presents lower digestible energy and $\mathrm{NE}_{\mathrm{L}}$ compared with barley grain (NRC, 2001), several studies showed no negative effects on production performance when barley is replaced with oat grain (Ekern et al., 2003; Fuhr, 2006; Gozho and Mutsvangwa, 2008; Yu et al., 2010).

Despite cereal grains being widely used in ruminant diets, the whole cereal grain is resistant to digestion by ruminants, mainly due to the protective seed coat and the ligneous hull that shields the groat from microbial degradation in the rumen (Morgan and Campling, 1978). Therefore, processing is required, to break the hull and expose the grain to microbial attachment and subsequent digestion. Processing techniques can also be applied to manipulate ruminal rate and extent of degradation and, hence, increase the availability for the rumen and small intestine (Svihus et al., 2005; Chrenkova et al., 2018). Several processing methods can be used to manipulate this rate of degradation. Pelleting is a common processing method for poultry feeds, but previous studies have suggested that feeding pelleted grains to cows could reduce DMI, with no effect on milk production (Gozho et al., 2008).

Previous research with the novel synchrotronradiation molecular spectroscopic approach (Yu, 2010) found that the processing-induced molecular structural 
changes to feed could be associated with nutrient utilization and availability (Zhang and Yu, 2012; Becker and $\mathrm{Yu}, 2013$; $\mathrm{Yu}$ and $\mathrm{Yu}, 2015)$. The sensitivity and responses of internal molecular structures to different processing methods varied significantly. However, to our knowledge, no study on the effects of different processing methods (rolling, pelleting, steam-flaking) has been performed for cool-season adapted oat grain.

Therefore, the objective of this study was to evaluate the effects of replacement of rolled barley grain by 3 types of processed oats (dry-rolled, steam-flaked, or pelleted) on the performance, total-tract digestibility, $\mathrm{N}$ balance, ruminal fermentation characteristics, and metabolic characteristics of lactating dairy cows.

\section{MATERIALS AND METHODS}

\section{Animals and Diets}

Eight lactating multiparous Holstein dairy cows (average of $715 \mathrm{~kg} \mathrm{BW} ; 79 \pm 12 \mathrm{DIM}$; parities $2.5 \pm 1.5$; average milk yield $51 \pm 6.9 \mathrm{~kg} / \mathrm{d}$; all values $\pm \mathrm{SD}$ ) were used in a replicated $4 \times 4$ Latin square design with 21-d experimental periods (17 d of dietary adaptation and $4 \mathrm{~d}$ of sample collection). Four cows in 1 Latin square were ruminally cannulated to allow measurement of ruminal fermentation characteristics. All cows were housed in individual tiestalls in the Rayner Dairy Teaching and Research Facility (University of Saskatchewan, Saskatoon, Canada) with free access to water, and 7-d adaptation was established before the beginning of the experimental period, for the animals to become accustomed to the new environment. The University of Saskatchewan Animal Care Committee approved the animal trial under Animal Use Protocol No. 19910012, and animals were cared for and handled in accordance with Canadian Council of Animal Care (CCAC, 1993) regulations.

Samples of oats (CDC Nasser, feed-type) and barley grain (feed-type) used in this study were obtained from commercial sellers by the Canadian Feed Research Centre (CFRC, University of Saskatchewan). Processing of the grains was also conducted in the CFRC, University of Saskatchewan, North Battleford, Canada. Two different production batches were made for all treatments. Pelleting was performed at $62^{\circ} \mathrm{C}$ in a pellet mill (UAS-Muyang, model MUZL350II; Muyang, Yangzhou, China) with a die inside diameter of $350 \mathrm{~mm}$ and hole area of $4 \mathrm{~mm}$, with a pellet durability index of $66 \%$. For steam-flaking, samples were steamed for 25 min at atmospheric pressure, and subsequently flakes were made at approximately $100^{\circ} \mathrm{C}$ (AT Ferrell $18 \times$ 39 Dual Drive; Bluffton, IN), before being transferred to the flaker cooler (Geelen Model VK $28 \times 28 \mathrm{KL}$; Windmolenven, the Netherlands). Rolled samples were made using a roller grinder (G.J. Vis Triple Pair $12 \times$ 20"; Oak Bluff, Manitoba, Canada), with final processing index of 50.9 for oats and 73.4 for barley.

The cows were fed diets containing $54 \%$ forage and $46 \%$ concentrate, with $15 \%$ of concentrate consisting of grains from 1 of the 4 treatments: rolled oats, flaked oats, pelleted oats, or rolled barley, as shown in Table 1. The diets were formulated using NDS Professional (Version 3, RUM\&N-NDS Professional, Reggio Nell'Emilia, Emilia-Romagna, Italy). Cows were fed daily at $0800 \mathrm{~h}$ as a TMR; refusals were collected every morning before feeding and weighed to estimate DMI. Feed offers were adjusted daily to allow for 5 to $10 \%$ refusal (on as-fed basis). Samples of alfalfa hay and barley silage were collected twice a week, and DM content was determined, allowing adjustment of the diet to maintain the forageto-concentrate ratio. Feed ingredients and orts were sampled in the last $4 \mathrm{~d}$ of each period and pooled by cow and by period before being ground through a 1-mm screen and submitted to chemical analysis.

\section{Milk Production and Composition}

Cows were milked 3 times a day, at 0500, 1200, and $2000 \mathrm{~h}$. Milk yield was recorded in the first $3 \mathrm{~d}$ of every collection period (d 18, 19, and 20), and milk samples were collected at every milking during the same period, preserved with potassium dichromate, and sent to CanWest DHI (Edmonton, Alberta, Canada) to be tested for milk fat (\%), protein (\%), lactose (\%), total solids (\%), milk urea N, and SCC, determined using a near-infrared analyzer (Foss System 4000, Foss Electric, Hillerød, Denmark). Yields of milk fat, protein, and lactose were calculated by multiplying the percentage of the component by the milk yield. Fat-corrected milk was determined as $3.5 \% \mathrm{FCM}=(0.434 \times \mathrm{kg}$ of milk $)$ $+(16.216 \times \mathrm{kg}$ of milk fat $)$. Energy-corrected milk was calculated as $\mathrm{ECM}=(0.327 \times \mathrm{kg}$ of milk $)+(12.95 \times$ $\mathrm{kg}$ of milk fat) $+(7.2 \times \mathrm{kg}$ of milk protein) (Chibisa et al., 2015). Feed efficiency was calculated as milk yield/ DMI, FCM/DMI, and ECM/DMI.

\section{Ruminal Characteristics}

Ruminal characteristics were analyzed on the last day of sampling (d 21), every $3 \mathrm{~h}$, starting immediately after feeding $(0800 \mathrm{~h})$ and ending immediately before the next morning feeding time, so the collected samples represented the 24 -h feeding cycle. The digesta was collected from 3 different areas of the rumen (cranial ventral, rumen ventral, and caudal ventral) and 
filtered through 4 layers of cheesecloth. The $\mathrm{pH}$ was measured with a pH meter (Accumet AP110, Thermo Fisher Scientific, Waltham, MA), and $10 \mathrm{~mL}$ was taken and immediately mixed with $2 \mathrm{~mL}$ of metaphosphoric acid $\left(\mathrm{H}_{2} \mathrm{PO}_{4}\right)$ at $25 \% \mathrm{wt} / \mathrm{vol}$ and stored at $-20^{\circ} \mathrm{C}$ for later determination of short-chain fatty acid (SCFA) content by gas chromatography, using the TRACE 1310 (Thermo Fisher Scientific) at the Ministry of Agriculture Strategic Feed Research Chair Laboratory (University of Saskatchewan).

\section{Total Collection of Urine and Feces}

For determination of apparent total-tract digestibility and $\mathrm{N}$ balance, a 3-d total collection of urine and feces was conducted from 0700 on d 18 to 0700 on d 20. Total urine output was collected using Foley blad- der catheters ( 26 Fr, 75-mL ribbed balloon, lubriciouscoated; C. R. Bard Inc., Covington, GA) Catheters were inserted at $0900 \mathrm{~h}$ on $\mathrm{d} 17$ and were connected to a urine collection container using a hose at 0800 on d 18 . Urine output was weighed, volume was quantified, and samples were collected at 1300, 1900, 0100, and 0700 daily. By the end of each sampling day, samples were pooled by cow and by day, according to the output, and a 10-mL aliquot was mixed with $40 \mathrm{~mL}$ of sulfuric acid $\left(\mathrm{H}_{2} \mathrm{SO}_{4}\right)$ and stored at $-20^{\circ} \mathrm{C}$ for analysis. Total $\mathrm{N}$ was measured using the Kjeldahl method, and uric acid content was quantified using a uric acid assay kit (Item No. 700320, Cayman Chemical, Ann Arbor, MI). The concentration of allantoin was quantified using the colorimetric method described by Cheng and Gomes (1992). Total purine derivative excretion per day was used to estimate microbial $\mathrm{N}$ yield as described by

Table 1. Ingredient composition of experimental diets fed to lactating Holstein cows as TMR

\begin{tabular}{|c|c|c|c|c|}
\hline \multirow[b]{2}{*}{ Item $^{1}$} & \multicolumn{4}{|c|}{ Diet } \\
\hline & Barley & Flaked oat & Rolled oat & Pellet oat \\
\hline \multicolumn{5}{|l|}{ Ingredient composition, $\%$} \\
\hline Barley silage & 36.82 & 36.82 & 36.82 & 36.82 \\
\hline Alfalfa hay & 17.33 & 17.33 & 17.33 & 17.33 \\
\hline Rolled barley & 15.54 & - & - & - \\
\hline Flaked oat & - & 15.54 & - & - \\
\hline Rolled oat & - & - & 15.54 & - \\
\hline Pelleted oat & - & - & - & 15.54 \\
\hline RP10 palmitic & 1.3 & 1.3 & 1.3 & 1.3 \\
\hline Canola meal & 8.63 & 8.63 & 8.63 & 8.63 \\
\hline Corn grain & 6.62 & 6.62 & 6.62 & 6.62 \\
\hline Soybean meal & 5.13 & 5.13 & 5.13 & 5.13 \\
\hline Peas & 3.98 & 3.98 & 3.98 & 3.98 \\
\hline Soybean hulls & 1.74 & 1.74 & 1.74 & 1.74 \\
\hline Urea & 0.11 & 0.11 & 0.11 & 0.11 \\
\hline Tallow & 0.80 & 0.80 & 0.80 & 0.80 \\
\hline Premix & 1.04 & 1.04 & 1.04 & 1.04 \\
\hline PotMag sulfate & 0.21 & 0.21 & 0.21 & 0.21 \\
\hline Sodium bicarbonate & 0.46 & 0.46 & 0.46 & 0.46 \\
\hline Limestone & 0.13 & 0.13 & 0.13 & 0.13 \\
\hline Rumensin & 0.01 & 0.01 & 0.01 & 0.01 \\
\hline Ameribond & 0.15 & 0.15 & 0.15 & 0.15 \\
\hline \multicolumn{5}{|l|}{ Chemical composition } \\
\hline DM & 53.16 & 52.62 & 54.41 & 53.80 \\
\hline $\mathrm{CP}, \%$ of DM & 16.96 & 16.56 & 16.75 & 17.03 \\
\hline $\mathrm{OM}, \%$ of DM & 83.54 & 83.52 & 83.74 & 83.53 \\
\hline Starch, \% of DM & 15.90 & 15.68 & 16.96 & 15.82 \\
\hline Ether extract, $\%$ of DM & 4.75 & 4.72 & 4.93 & 4.80 \\
\hline NDF, $\%$ of DM & 34.47 & 35.55 & 33.65 & 34.51 \\
\hline $\mathrm{ADF}, \%$ of $\mathrm{DM}$ & 23.02 & 23.95 & 22.40 & 22.91 \\
\hline $\mathrm{NE}_{\mathrm{L}}, \mathrm{Mcal} / \mathrm{kg}$ & 1.65 & 1.63 & 1.67 & 1.65 \\
\hline
\end{tabular}

${ }^{1}$ Mineral-vitamin premix contained 16\% DM Ca, 7\% DM P, 7\% DM Mg, 2\% DM K, $10 \%$ DM Cl, 1.25\% DM S, $1,507 \mathrm{mg} / \mathrm{kg}$ of Mn, $678 \mathrm{mg} / \mathrm{kg}$ of Cu, $1,005 \mathrm{mg} / \mathrm{kg}$ of Fe, 2,513 mg/kg of Zn, $80 \mathrm{mg} / \mathrm{kg}$ of I, $30 \mathrm{mg} / \mathrm{kg}$ of Co, $20 \mathrm{mg} / \mathrm{kg}$ of Se, $256 \mathrm{IU} / \mathrm{kg}$ of vitamin $\mathrm{D}_{3}, 2,010 \mathrm{IU} / \mathrm{kg}$ of vitamin E. Silage composition: $\mathrm{DM}=39.5 \%$, NDF $=44.3 \%$ of DM, $\mathrm{CP}=12.5 \%$ of DM, starch $=16.9 \%$ of DM. Alfalfa composition: $\mathrm{DM}=82 \%, \mathrm{CP}=17.5 \%$ of $\mathrm{DM}, \mathrm{NDF}=50.1 \%$ of DM. Oat composition: $\mathrm{DM}=86 \%, \mathrm{CP}=10.7 \%$ of $\mathrm{DM}$, starch $=44.6 \%$ of $\mathrm{DM}$, ether extract $=4.5 \%$ of DM. Barley composition: $\mathrm{DM}=86 \%, \mathrm{CP}=9.2 \%$ of DM, starch $=54.7 \%$ of DM, ether extract $=1.7 \%$ of DM. RP10 palmitic manufactured by Scothorn Nutrition, Grand Pré, Nova Scotia, Canada; PotMag sulfate manufactured by Jefo, Saint-Hyacinthe, Quebec, Canada; Rumensin manufactured by Elanco Animal Health, Greenfield, IN; Ameribond manufactured by LignTech USA Inc., Rothschild, Wisconsin. 
Cheng and Gomes (1992). Nitrogen retained was calculated as intake $\mathrm{N}-$ fecal $\mathrm{N}$ - urinary $\mathrm{N}-$ milk $\mathrm{N}$. Milk $\mathrm{N}$ was determined as milk $\mathrm{CP} \div 6.38$.

Feces were collected into large steel trays, which were positioned to cover the gutter behind every stall. Daily fecal output was measured by weight, taken at the same time points as urine sampling, mixed thoroughly before $3 \%$ was sampled for each time point. At the end of each collection day, samples of feces were pooled by cow by day and dried at $60^{\circ} \mathrm{C}$ for $48 \mathrm{~h}$ (AOAC International, 1990, method 930.15) and ground through a 1-mm screen for analysis of DM, OM, CP, NDF, and starch (AOAC International, 2005)

\section{Blood Sampling}

On the last day of sampling (d 21), blood samples were collected every $6 \mathrm{~h}$ at 0800,1400 , and 2000, and 0200 and $0800 \mathrm{~h}$ the next morning immediately before feeding, via a jugular vein catheter into a $10-\mathrm{mL}$ Vacutainer tube containing heparin (Becton Dickinson, Franklin Lakes, NJ). Blood samples were placed in ice water immediately after collection until all samples were obtained, and then centrifuged at $1,200 \times \mathrm{g}$ for 15 min at $4^{\circ} \mathrm{C}$. Plasma was subsequently stored at $-20^{\circ} \mathrm{C}$ until analysis. $\beta$-Hydroxybutyrate level was determined according to Williamson et al. (1962), BUN level was determined using the method of Fawcett and Scott (1960), and plasma glucose concentration was determined using a glucose oxidase and peroxidase enzyme and dianisidine dihydrochloride method as described by Oba et al. (2010).

\section{Statistical Analysis}

The data were analyzed using Proc Mixed on SAS 9.4 (SAS Institute, Cary, NC). Milk yield and composition, apparent total-tract digestibility, urinary and blood characteristics, and ruminal SCFA levels were analyzed using the following model:

$$
\mathrm{Y}_{\mathrm{ijk} l}=\mu+\mathrm{S}_{\mathrm{i}}+\mathrm{T}_{\mathrm{j}}+\mathrm{P}_{\mathrm{k}}+\mathrm{C}_{\mathrm{l}}+\mathrm{e}_{\mathrm{ijk} \mathrm{l}},
$$

where $Y_{i j k}$ was the observation of the dependent variable, $\mu$ was the population mean, $S_{i}$ was the effect of square $i, T_{j}$ was the fixed effect of treatment $j, P_{k}$ was the fixed effect of period $\mathrm{k}, \mathrm{C}_{1}$ was the random effect of the cow, and $\mathrm{e}_{\mathrm{ijkl}}$ was error associated with the observation. Before analysis, the best variance and covariance structure model was selected based on the Akaike and Bayesian information criteria values.

For all statistical analyses, significance was declared at $P<0.05$ and trends at $0.05 \leq P<0.10$. The dif- ferences among the treatments were compared using a multiple comparison test following the Tukey method. Contrast statement was used to compare the differences between barley and oat grains.

\section{RESULTS AND DISCUSSION}

\section{DMI, Milk Production, and Milk Composition}

Table 2 shows DMI, milk yield, milk composition, and feed efficiency. Dry matter intake was higher $(P=$ 0.01 ) for cows fed the pelleted oats-based diet than for cows on the rolled oats-based TMR. Cows fed rolled barley, flaked oats, and rolled oats consumed 1.90, 2.06, and $3.42 \mathrm{~kg}$ less, respectively, than cows fed the pelleted oats diet. However, milk yield was higher $(P<$ 0.01 ) for cows fed the rolled oats-based TMR compared with the other diets. Overall, cows fed oat-based diets produced an average of $1.17 \mathrm{~kg}$ more milk $(P<0.01)$ than cows fed the barley-based TMR. Several comparative studies have investigated production responses in trials comparing grain types and different processing methods (Gozho and Mutsvangwa, 2008; Yu et al., 2010; Safaei and Yang, 2017). Additionally, some of the studies in the literature showed variable production responses. Gozho and Mutsvangwa (2008) reported no differences in DMI or milk yield for cows fed TMR containing barley grain, corn grain, wheat, or oat grain. Ekern et al. (2003), on the other hand, reported higher milk yield for cows fed oat grain.

Fat percentages ranged from 4.00 to $3.62 \%$, with cows fed pelleted oat-based TMR showing the lowest $(P<0.01)$ fat percentage. Milk fat depression has been previously reported for cows fed a pelleted concentrate (dos Santos et al., 2011). The increased release of fat by pelleted oats, if it happens in the rumen, could modify FA metabolism and change the biohydrogenation pathways. Dos Santos et al. (2011) also showed that pelleting increased trans-C18:1 FA concentration in milk, which is correlated with milk fat depression. Nonetheless, fat yield and FCM were not significantly different $(P>0.10)$ across the treatments. Protein percentage was higher $(P<0.01)$ for the barley-based TMR and lower for the flaked oats-based diet. In contrast, Cooke et al. (2008) reported higher milk protein production, while maintaining protein and fat percentage, and fat production. Similarly, Zhong et al. (2008) reported similar fat production for cows fed finely ground corn or steam-flaked corn-based TMR, but cows fed steamflaked corn produced $0.21 \%$ more protein. Milk urea N showed no significant difference between treatments $(P$ $=0.27)$. The SCC ranged from 32.56 to $39.35 \times 10^{3}$ cells $/ \mathrm{mL}$ and showed no difference $(P=0.83)$ between treatments. The lower DMI of cows fed a rolled oats- 
Table 2. Dry matter intake, milk yield, and milk composition in lactating Holstein cows fed diets containing rolled barley, rolled oats, flaked oats, or pelleted oats; multi-treatment comparisons using Tukey method

\begin{tabular}{|c|c|c|c|c|c|c|}
\hline \multirow[b]{2}{*}{ Item $^{1}$} & \multicolumn{3}{|c|}{ Oats } & \multirow[b]{2}{*}{ Barley } & \multirow[b]{2}{*}{ SEM } & \multirow[b]{2}{*}{$P$-value } \\
\hline & Rolled & Flaked & Pelleted & & & \\
\hline DMI, kg/d & $28.19^{\mathrm{b}}$ & $29.55^{\mathrm{ab}}$ & $31.61^{\mathrm{a}}$ & $29.71^{\mathrm{ab}}$ & 1.010 & 0.01 \\
\hline Milk yield, kg/d & $49.23^{\mathrm{a}}$ & $46.55^{\mathrm{b}}$ & $47.32^{\mathrm{b}}$ & $46.53^{\mathrm{b}}$ & 1.970 & $<0.01$ \\
\hline $3.5 \% \mathrm{FCM}, \mathrm{kg} / \mathrm{d}$ & 51.54 & 48.17 & 50.47 & 50.09 & 1.778 & 0.17 \\
\hline ECM, $\mathrm{kg} / \mathrm{d}$ & 50.38 & 47.30 & 49.51 & 49.23 & 1.681 & 0.15 \\
\hline Fat, \% & $4.00^{\mathrm{a}}$ & $3.69^{\mathrm{c}}$ & $3.62^{\mathrm{d}}$ & $3.93^{\mathrm{b}}$ & 0.165 & $<0.01$ \\
\hline Fat yield, $\mathrm{kg} / \mathrm{d}$ & 1.89 & 1.74 & 1.78 & 1.86 & 0.078 & 0.11 \\
\hline Protein, $\%$ & $2.94^{\mathrm{b}}$ & $2.92^{\mathrm{c}}$ & $2.95^{\mathrm{b}}$ & $3.03^{\mathrm{a}}$ & 0.088 & $<0.01$ \\
\hline Protein yield, $\mathrm{kg} / \mathrm{d}$ & $1.42^{\mathrm{a}}$ & $1.34^{\mathrm{b}}$ & $1.41^{\mathrm{ab}}$ & $1.39^{\mathrm{ab}}$ & 0.045 & 0.03 \\
\hline Lactose, \% & 4.42 & 4.35 & 4.40 & 4.43 & 0.029 & 0.06 \\
\hline Lactose yield, $\mathrm{kg} / \mathrm{d}$ & $2.15^{\mathrm{a}}$ & $1.99^{\mathrm{b}}$ & $2.15^{\mathrm{ab}}$ & $2.06^{\mathrm{ab}}$ & 0.087 & 0.02 \\
\hline MUN, mg/dL & 18.81 & 18.75 & 18.28 & 18.59 & 0.603 & 0.27 \\
\hline Total solids, \% & $12.37^{\mathrm{ab}}$ & $12.18^{\mathrm{b}}$ & $12.01^{\mathrm{c}}$ & $12.47^{\mathrm{a}}$ & 0.314 & $<0.01$ \\
\hline $\mathrm{SCC}, \times 10^{3} \mathrm{cell} / \mathrm{mL}$ & 39.35 & 32.56 & 38.39 & 33.97 & 10.18 & 0.83 \\
\hline \multicolumn{7}{|l|}{ Feed efficiency } \\
\hline Milk yield/DMI & $1.70^{\mathrm{a}}$ & $1.52^{\mathrm{b}}$ & $1.64^{\mathrm{ab}}$ & $1.55^{\mathrm{b}}$ & 0.049 & $<0.01$ \\
\hline FCM/DMI & $1.81^{\mathrm{a}}$ & $1.64^{\mathrm{b}}$ & $1.66^{\mathrm{b}}$ & $1.67^{\mathrm{ab}}$ & 0.058 & 0.02 \\
\hline $\mathrm{ECM} / \mathrm{DMI}$ & $1.73^{\mathrm{a}}$ & $1.62^{\mathrm{ab}}$ & $1.64^{\mathrm{ab}}$ & $1.64^{\mathrm{b}}$ & 0.049 & 0.01 \\
\hline
\end{tabular}

${ }^{a-d}$ Means with different superscript letters in the same row are significantly different $(P<0.05)$.

based diet affected the feed efficiency observed in this study. Ratios of milk yield to DMI and FCM to DMI were both higher for rolled oats $(P \leq 0.02)$ compared with steam-flaked oats.

\section{Ruminal Characteristics}

Ruminal SCFA concentration is presented in Table 3. Individual concentrations for most SCFA were not affected by dietary treatment; however, the concentration of acetate was significantly lower $(P<0.01)$ for cows fed the pelleted oats-based diet compared with rolled oats or barley. Increased acetate supply is linked to milk fat production (Urrutia and Harvatine, 2017), and the decreased amount of acetate concentration in cows fed the pellet oats-based diet may explain the lower milk fat percentage caused by this diet. Total SCFA concentration was higher $(P=0.01)$ for cows fed rolled barley compared with rolled or pelleted oats.

Mean ruminal $\mathrm{pH}$ over a 24 -h period was unaffected $(P=0.63)$ by dietary treatment, with mean values of $6.20,6.08,6.21$, and 6.15 for rolled oats, flaked oats, pelleted oats, and barley, respectively (Table 1). In the 9-h and 12-h post-feeding points, however, flaked oats exhibited the lowest $\mathrm{pH}$ numbers, whereas pelleted oats and rolled barley showed the highest values (at 9 and 12 h, respectively; $P=0.03$ and $P=0.04$, respectively) (Figure 1). The $\mathrm{pH}$ declined more quickly for the steamflaking and pelleting up until $6 \mathrm{~h}$ post-feeding, but the recovery for cows fed pelleted oats was faster and higher

Table 3. Ruminal fermentation characteristics in lactating Holstein cows fed diets containing rolled barley, rolled oats, flaked oats, or pelleted oats; multi-treatment comparisons using Tukey method

\begin{tabular}{lccccccc}
\hline & \multicolumn{5}{c}{ Oats } & & \\
\cline { 2 - 4 } Item & Rolled & Flaked & Pelleted & Barley & SEM & $P$-value \\
\hline Mean ruminal pH & 6.20 & 6.08 & 6.21 & 6.15 & 0.087 & 0.63 \\
SCFA concentrations, ${ }^{1}{ }^{2} \mathrm{~m} M$ & & & & & & \\
Acetate & $58.98^{\mathrm{a}}$ & $58.79^{\mathrm{ab}}$ & $54.84^{\mathrm{b}}$ & $61.11^{\mathrm{a}}$ & 2.304 & $<0.01$ \\
Propionate & 21.96 & 23.86 & 23.11 & 22.86 & 1.629 & 0.32 \\
Butyrate & 10.45 & 10.71 & 10.97 & 10.57 & 0.502 & 0.08 \\
Isobutyrate & 0.78 & 0.75 & 0.74 & 0.82 & 0.039 & 0.15 \\
Valerate & 1.31 & 1.27 & 1.42 & 1.39 & 0.098 & 0.04 \\
Isovalerate & 1.37 & 1.28 & 1.23 & 1.34 & 0.171 & 0.06 \\
Caprionic & 0.39 & 0.37 & 0.46 & 0.48 & 0.049 & 0.28 \\
Total SCFA & $93.62^{\mathrm{b}}$ & $96.71^{\mathrm{ab}}$ & $92.86^{\mathrm{b}}$ & $100.45^{\mathrm{a}}$ & 3.976 & 0.01 \\
Acetate:propionate & 2.59 & 2.54 & 2.44 & 2.75 & 0.128 & 0.42 \\
\hline
\end{tabular}

${ }^{1} \mathrm{SCFA}=$ short-chain fatty acid.

${ }^{\mathrm{a}, \mathrm{b}}$ Means with different superscript letters in the same row are significantly different $(P<0.05)$. 


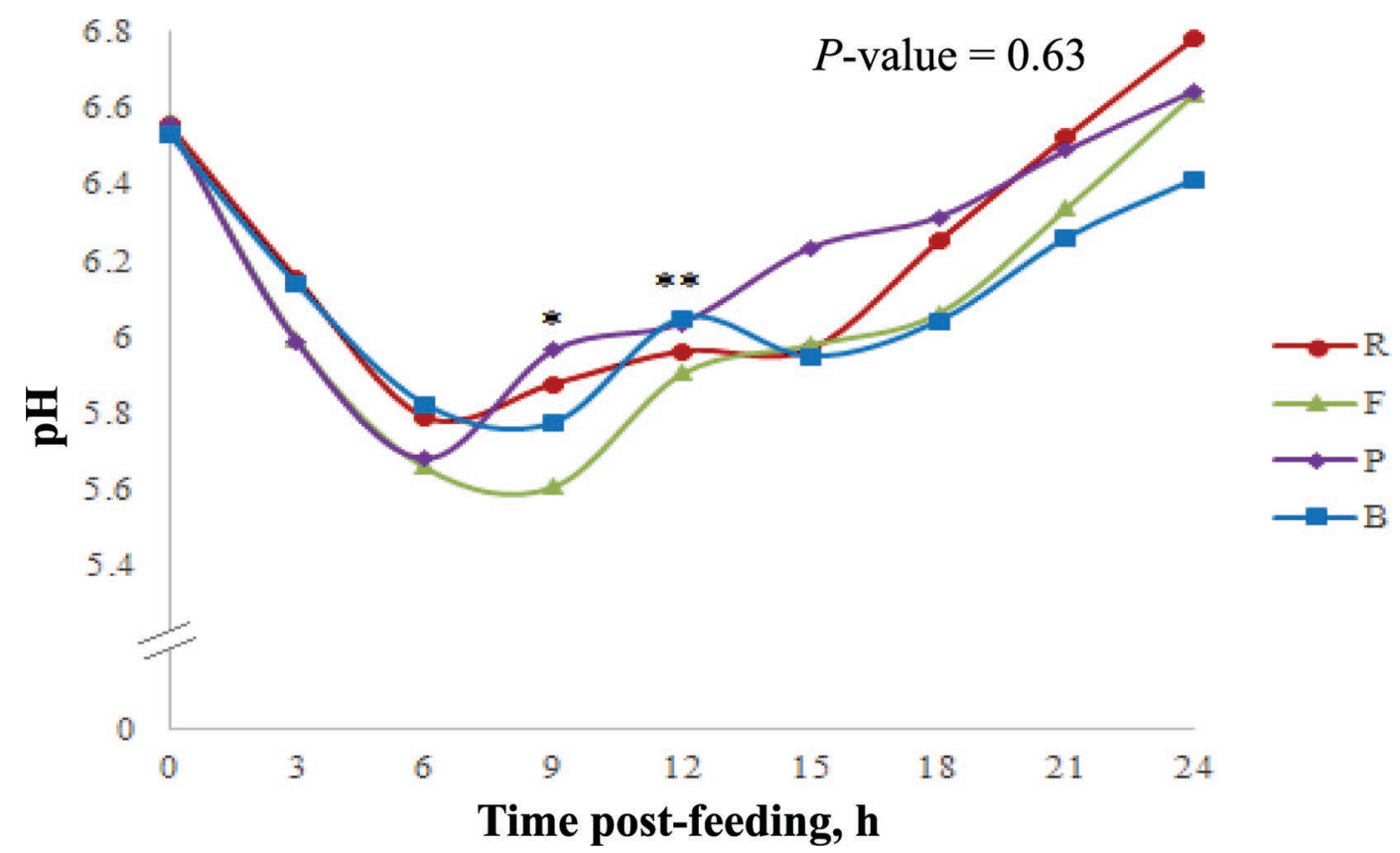

Figure 1. Ruminal $\mathrm{pH}$ of lactating Holstein cows fed diets containing rolled oats $(\mathrm{R})$, flaked oats $(\mathrm{F})$, pelleted oats $(\mathrm{P})$, or rolled barley (B). *Significant difference between $\mathrm{F}$ and $\mathrm{P}(P=0.03)$; **significant difference between $\mathrm{F}$ and $\mathrm{B}(P=0.04)$.

compared with flaked oats or rolled barley. Previous studies also reported higher ruminal $\mathrm{pH}$ values for cows fed pelleted concentrates (dos Santos et al., 2011). Oat grains present a higher starch degradation rate and extent in the rumen compared with barley grain (HerreraSaldana et al., 1990); however, no difference in $\mathrm{pH}$ was observed between grains in this study, similar to the results obtained by Gozho and Mutsvangwa (2008). This might have resulted from the high concentrations of NDF across all dietary treatments, which can result in high ruminal buffering. Dietary NDF can stimulate chewing and, consequently, saliva production, which can serve as a buffer for the production of ruminal acid.

\section{Nutrient Digestibility}

Apparent total-tract digestibility of DM, OM, CP, NDF, and starch are shown in Table 4. Total-tract digestibility of DM, OM and CP were not affected by dietary treatment $(P \geq 0.14)$. Total-tract NDF digest-

Table 4. Apparent total-track nutrient digestibility of lactating Holstein cows fed diets containing rolled barley, rolled oats, flaked oats, or pelleted oats; multi-treatment comparisons using Tukey method

\begin{tabular}{|c|c|c|c|c|c|c|}
\hline Item & \multicolumn{3}{|c|}{ Oats } & Barley & SEM & $P$-value \\
\hline Apparent digestion, $\%$ of DMI & 63.96 & 66.5 & 66.08 & 66.27 & 1.078 & 0.25 \\
\hline Apparent digestion, $\mathrm{kg} / \mathrm{d}$ & 18.40 & 20.02 & 20.19 & 19.93 & 0.763 & 0.23 \\
\hline \multicolumn{7}{|l|}{ OM } \\
\hline Apparent digestion, $\%$ of OM intake & 65.35 & 67.51 & 66.92 & 67.26 & 1.147 & 0.48 \\
\hline Apparent digestion, $\%$ of $\mathrm{CP}$ intake & 69.13 & 71.37 & 71.20 & 70.36 & 0.988 & 0.26 \\
\hline Apparent digestion, $\mathrm{kg} / \mathrm{d}$ & 3.24 & 3.50 & 3.62 & 3.50 & 0.139 & 0.14 \\
\hline \multicolumn{7}{|l|}{ NDF } \\
\hline Apparent digestion, $\%$ of NDF intake & $54.16^{\mathrm{b}}$ & $57.49^{\mathrm{ab}}$ & $59.56^{\mathrm{a}}$ & $59.92^{\mathrm{a}}$ & 1.365 & 0.03 \\
\hline Apparent digestion, $\mathrm{kg} / \mathrm{d}$ & 5.06 & 5.91 & 5.96 & 6.03 & 0.665 & 0.09 \\
\hline \multicolumn{7}{|l|}{ Starch } \\
\hline Apparent digestion, $\%$ of starch intake & $92.38^{\mathrm{a}}$ & $92.79^{\mathrm{a}}$ & $92.52^{\mathrm{a}}$ & $89.04^{\mathrm{b}}$ & 0.588 & $<0.01$ \\
\hline
\end{tabular}

\footnotetext{
${ }_{\mathrm{a}, \mathrm{b}}$ Means with different superscript letters in the same row are significantly different $(P<0.05)$.
} 
ibility ranged from 54.16 to $59.92 \%$ of NDF intake and it was lower $(P=0.03)$ for rolled oats compared with pellet oats and rolled barley-based diets. Apparent total-tract starch digestibility was lower $(P<0.01)$ for rolled barley when compared with all 3 oats grainbased diets (rolled, steam-flaked and pelleted). In dairy cows, the main site for cereal grain starch digestion is the rumen, and with oats grain showing a faster and more extensive starch degradation in the rumen compared with barley (Herrera-Saldana et al., 1990) it was expected that oats-based TMR would have a higher starch digestibility. Moran (1986) also described a higher digestibility of starch for cows fed complete diets with rolled oats when compared with rolled barley or wheat-based diets.

\section{Urine Characteristics, N Balance, and Microbial N Flow}

Excretion of urinary purine derivatives and microbial $\mathrm{N}$ supply to the small intestine are shown in Table 5. Allantoin output did not differ among treatments $(P=$ $0.16)$. Uric acid excretion was higher $(P=0.05)$ for cows fed the pelleted oats-based TMR compared with rolled barley (18.67 vs. $16.46 \mathrm{mmol} / \mathrm{d}$, respectively). Gozho et al. (2008) also showed no significant difference in allantoin or purine derivatives excretion between cows fed rolled or pelleted barley. Total purine excretion did not differ among treatments $(P=0.17)$. Consequently, the calculated intestinal flow of microbial $\mathrm{N}$ was also unaffected by dietary treatment $(P=0.16)$. Theurer et al. (1999) pointed out that increasing ruminal starch digestibility increased the microbial N supply; however, in our study, the extra $200 \mathrm{~g}$ of starch consumed by cows fed pelleted oats did not increase microbial $\mathrm{N}$ production.
Nitrogen intake was similar for cows across all diets (Table 6). However, as a percentage of $\mathrm{N}$ intake, urinary $\mathrm{N}$ excretion was lower for cows fed rolled barley compared with oats $(P=0.03)$. Total urinary excretion in grams per day did not differ between treatments $(P$ $=0.87)$. Fecal $\mathrm{N}$ excretion did not show any significant difference between the treatments studied. Milk N excretion was higher for cows fed the rolled oats-based TMR compared with flaked oats $(P=0.03)$, and as a percentage of $\mathrm{N}$ intake, the rolled oats-based diet also showed a higher excretion level $(P<0.01)$. Higher milk $\mathrm{N}$ excretion was expected for the rolled oats-based diet, because cows fed this diet presented a higher milk yield daily $(49.23 \mathrm{~kg} / \mathrm{d})$. The $\mathrm{N}$ balance ( $\mathrm{N}$ intake $-\mathrm{N}$ excretion) varied from 1.6 to $67.8 \mathrm{~g} / \mathrm{d}$; however, despite the numerical difference, no statistical difference was found between treatments $(P=0.28)$.

\section{Blood Characteristics}

The measured blood metabolites are shown in Table 5. Plasma concentrations of urea nitrogen did not differ between treatments $(P=0.58)$. In dairy cows, the resulting ammonia that is not used for microbial protein synthesis in the rumen is absorbed into the portal blood and subsequently converted to urea in the liver (NRC, 2001). Plasma glucose did not respond to dietary treatments $(P=0.82)$. Generally, due to the extensive degradation of starch in the rumen, the glucose absorbed in the small intestine is limited, so glucose in the plasma mainly arises from gluconeogenesis in the liver, with rumen-derived propionate as the major precursor to glucose formation (Gozho and Mutsvangwa, 2008). In this study, rumen propionate concentrations did not show a significant difference between dietary treatments, which may explain the lack of difference

Table 5. Blood metabolites, urine output, urinary purine derivatives excretion, and microbial N supply of lactating Holstein cows fed diets containing rolled barley, rolled oats, flaked oats, or pelleted oats; multi-treatment comparisons using Tukey method

\begin{tabular}{|c|c|c|c|c|c|c|}
\hline Item & \multicolumn{3}{|c|}{ Oats } & Barley & SEM & $P$-value \\
\hline Output, kg/d & 36.33 & 36.37 & 37.45 & 38.38 & 1.555 & 0.19 \\
\hline Allantoin, $\mathrm{mmol} / \mathrm{d}$ & 341.86 & 335.08 & 294.47 & 327.96 & 26.164 & 0.16 \\
\hline Uric acid, $\mathrm{mmol} / \mathrm{d}$ & $17.77^{\mathrm{ab}}$ & $17.55^{\mathrm{ab}}$ & $18.67^{\mathrm{a}}$ & $16.46^{\mathrm{b}}$ & 2.049 & 0.05 \\
\hline Purine derivatives, $\mathrm{mmol} / \mathrm{d}$ & 360.12 & 350.38 & 313.11 & 345.99 & 28.106 & 0.17 \\
\hline \multicolumn{7}{|l|}{ Blood metabolites } \\
\hline BUN, mg/dL & 19.13 & 18.48 & 18.75 & 17.97 & 0.605 & 0.58 \\
\hline Plasma glucose, $\mathrm{mg} / \mathrm{dL}$ & 46.57 & 47.06 & 45.86 & 45.39 & 1.249 & 0.82 \\
\hline Plasma BHB, mg/dL & 8.76 & 9.52 & 8.94 & 8.98 & 0.287 & 0.10 \\
\hline
\end{tabular}

\footnotetext{
${ }^{\mathrm{a}, \mathrm{b}}$ Means with different superscript letters in the same row are significantly different $(P<0.05)$.
} 
Table 6. Nitrogen balance in lactating Holstein cows fed diets containing rolled barley, rolled oats, flaked oats, or pelleted oats; multi-treatment comparisons using Tukey method

\begin{tabular}{|c|c|c|c|c|c|c|}
\hline \multirow[b]{2}{*}{ Item } & \multicolumn{3}{|c|}{ Oats } & \multirow[b]{2}{*}{ Barley } & \multirow[b]{2}{*}{ SEM } & \multirow[b]{2}{*}{$P$-value } \\
\hline & Rolled & Flaked & Pelleted & & & \\
\hline $\mathrm{N}$ intake, $\mathrm{g} / \mathrm{d}$ & 746 & 770 & 816 & 797 & 31.1 & 0.13 \\
\hline \multicolumn{7}{|l|}{ Urinary $\mathrm{N}$ excretion } \\
\hline $\mathrm{N}, \mathrm{g} / \mathrm{d}$ & 296 & 292 & 295 & 302 & 15.9 & 0.87 \\
\hline $\mathrm{N}, \%$ of $\mathrm{N}$ intake & 38.48 & 33.31 & 38.53 & 36.19 & 1.632 & 0.10 \\
\hline \multicolumn{7}{|l|}{ Fecal N excretion } \\
\hline $\mathrm{N}, \mathrm{g} / \mathrm{d}$ & 231 & 220 & 234 & 235 & 11.7 & 0.36 \\
\hline $\mathrm{N}, \%$ of $\mathrm{N}$ intake & 30.85 & 28.34 & 28.80 & 29.67 & 1.042 & 0.26 \\
\hline \multicolumn{7}{|l|}{ Milk N } \\
\hline Milk, g/d & $223^{\mathrm{a}}$ & $211^{\mathrm{b}}$ & $221^{\mathrm{ab}}$ & $219^{\mathrm{ab}}$ & 7.1 & 0.03 \\
\hline Milk, $\%$ of $\mathrm{N}$ intake & $29.05^{\mathrm{a}}$ & $27.06^{\mathrm{c}}$ & $28.39^{\mathrm{b}}$ & $28.47^{\mathrm{b}}$ & 0.847 & $<0.01$ \\
\hline $\mathrm{N}$ balance, $\mathrm{g} / \mathrm{d}$ & 1.6 & 48.5 & 67.8 & 35.6 & 28.59 & 0.28 \\
\hline
\end{tabular}

${ }^{\mathrm{a}-\mathrm{c}}$ Means with different superscript letters in the same row are significantly different $(P<0.05)$.

in plasma glucose observed in the experiment. Blood concentration of BHB was not affected by treatment $(P=0.10)$.

\section{CONCLUSIONS}

This study showed that feeding rolled oats, rolled barley, or flaked oats as concentrate in a TMR resulted in similar levels of DMI but that feeding pelleted oats can increase DMI. Despite the higher nutrient consumption by cows fed a pelleted oats-based TMR, production of milk and fat percentage were depressed; however, milk fat yield was not affected by dietary treatments, mainly because of the higher numerical production of milk by cows fed the pelleted oats-based diet compared with flaked oats. Acetate concentration was lower for the pelleted oats-based diet compared with rolled oats, which might explain the fat depression caused by the pelleted oats diet. Daily mean $\mathrm{pH}$ was unaffected. Digestibility of DM, OM, and $\mathrm{CP}$ was similar across all diets; however, starch digestibility was higher for oatsbased diets than for the barley-based diet. Measured blood metabolites (urea, glucose, and BHB) were similar across all treatments. Purine derivative excretion and microbial $\mathrm{N}$ supply were not affected by dietary treatments. Overall, cows fed dry-rolled oats produced more milk and showed the highest fat percentage compared with steam-flaked or pelleted oats or dry-rolled barley. Based on these results, feeding a TMR with dry-rolled oats provides an opportunity to increase milk production without degrading cow health and possibly may allow higher economic returns for dairy farmers.

\section{ACKNOWLEDGMENTS}

The authors acknowledge the Ministry of Agriculture Strategic Research Chair (PY) Program fund from the
Prairie Oat Growers Association (POGA), the Natural Sciences and Engineering Research Council of Canada (NSERC-Individual Discovery Grant and NSERCCRD Grant), the Saskatchewan Pulse Growers (SPG), the SaskCanola, Saskatchewan Agriculture Strategic Research Chair Program Fund, the Agricultural Development Fund (ADF), the SaskMilk, the Saskatchewan Forage Network (SNK), and the Western Grain Research Foundation (WGRF).

\section{REFERENCES}

AOAC International. 1990. Official Methods of Analysis. 15th ed. AOAC International, Gaithersburg, MD.

AOAC International. 2005. Official Methods of Analysis. 18th ed. AOAC International, Gaithersburg, MD.

Becker, P. M., and P. Yu. 2013. What makes protein indigestible from tissue-related, cellular, and molecular aspects? Mol. Nutr. Food Res. 57:1695-1707. https://doi.org/10.1002/mnfr.201200592.

CCAC (Canadian Council of Animal Care). 1993. Guide to Care and Use of Experimental Animals. 2nd ed. Vol. 1. CCAC, Ottawa, Canada.

Cheng, X. B., and M. J. Gomes. 1992. Estimation of microbial protein supply to sheep and cattle based on urinary excretion of purine derivatives - An overview of technical details. International Feed Research Unit, Rowett Research Institute, Aberdeen, UK.

Chibisa, G. E. P. Gorka, G. B. Penner, R. Berthiaume, and T. Mutsvangwa. 2015. Effects of partial replacement of dietary starch from barley or corn with lactose on ruminal function, short-chain fatty acid absorption, nitrogen utilization, and production performance of dairy cows. J. Dairy Sci. 98:2627-2640. https://doi.org/ $10.3168 /$ jds.2014-8827.

Chrenkova, M., Z. Formelova, Z. Ceresnakova, C. Dragomir, M. Rajsky, A. Cismileanu, and M. R. Weisbjerg. 2018. Rumen undegradable protein (RUP) and its intestinal digestibility after steam flaking of cereal grains. Czech J. Anim. Sci. 63:160-166. https:// doi.org/10.17221/74/2017-CJAS.

Cooke, K. M., J. K. Bernard, and J. W. West. 2008. Performance of dairy cows fed annual ryegrass silage and corn silage with steamflaked or ground corn. J. Dairy Sci. 91:2417-2422. https://doi.org/ 10.3168/jds.2007-0715.

dos Santos, W. B. R., G. T. D. Santos, D. C. da Silva-Kazama, U. Cecato, F. E. de Marchi, J. V. Visentainer, and H. V. Petit. 2011. Production performance and milk composition of grazing dairy cows fed pelleted or non-pelleted concentrates treated with or without lignosulfonate and containing ground sunflower seeds. 
Anim. Feed Sci. Technol. 169:167-175. https://doi.org/10.1016/j .anifeedsci.2011.06.015.

Ekern, A., Ø. Havrevoll, A. Haug, J. Berg, P. Lindstad, and S. Skeie. 2003. Oat and barley based concentrate supplements for dairy cows. Acta Agric. Scand. A Anim. Sci. 53:65-73. https://doi.org/ 10.1080/09064700310012476.

Fawcett, J. K., and J. E. Scott. 1960. A rapid and precise method for the determination of urea. J. Clin. Pathol. 13:156-159.

Fuhr, L. G. M. 2006. Low lignin hull, high oil groat oat grain in lactating dairy cow rations. Master's thesis, University of Saskatchewan, Saskatoon. Canada.

Gozho, G. N., M. R. Hobin, and T. Mutsvangwa. 2008. Interactions between barley grain processing and source of supplemental dietary fat on nitrogen metabolism and urea-nitrogen recycling in dairy cows. J. Dairy Sci. 91:247-259. https://doi.org/10.3168/jds .2007-0407.

Gozho, G. N., and T. Mutsvangwa. 2008. Influence of carbohydrate source on ruminal fermentation characteristics, performance, and microbial protein synthesis in dairy cows. J. Dairy Sci. 91:27262735. https://doi.org/10.3168/jds.2007-0809.

Herrera-Saldana, R. E., J. T. Huber, and M. H. Poore. 1990. Dry matter, crude protein, and starch degradability of five cereal grains. J. Dairy Sci. 73:2386-2393. https://doi.org/10.3168/jds.S0022 $-0302(90) 78922-9$.

Moran, J. B. 1986. Cereal grains in complete diets for dairy cows: A comparison of rolled barley, wheat and oats and of three methods of processing oats. Anim. Prod. 43:27-36. https://doi.org/10 $.1017 /$ S0003356100018316

Morgan, C. A., and R. C. Campling. 1978. Digestibility of whole barley and oat grains by cattle of different ages. Anim. Prod. 27:323329. https://doi.org/10.1017/S0003356100036217.

National Research Council. 2001. Nutrient Requirements of Dairy Cattle. 7th rev. ed. Natl. Acad. Press, Washington, DC. https:// doi.org/10.17226/9825

Oba, M., G. B. Penner, T. D. Whyte, and K. Wierenga. 2010. Effects of feeding triticale dried distillers grains plus solubles as a nitrogen source on productivity of lactating dairy cows. J. Dairy Sci. 93:2044-2052. https://doi.org/10.3168/jds.2009-2454.

Safaei, K., and W. Yang. 2017. Effects of grain processing with focus on grinding and steam-flaking on dairy cow performance. Pages 117-133 in Herbivores. V. D. C. Shields, ed. InTech Open Ltd., London, UK. https://doi.org/10.5772/67344

Statistics Canada. 2018. Table 32-10-0359-01: Estimated areas, yield, production, average farm price and total farm value of principal field crops, in metric and imperial units. Accessed Feb. 4 2019. https://www150.statcan.gc.ca/t1/tbl1/en/tv.action?pid= 3210035901
Svihus, B., A. K. Uhlen, and O. M. Harstad. 2005. Effect of starch granule structure, associated components and processing on nutritive value of cereal starch: A review. Anim. Feed Sci. Technol. 122:303-320. https://doi.org/10.1016/j.anifeedsci.2005.02.025.

Theurer, C. B., J. T. Huber, A. Delgado-Elorduy, and R. Wanderley. 1999. Invited review: Summary of steam-flaking corn or sorghum grain for lactating dairy cows. J. Dairy Sci. 82:1950-1959. https:/ /doi.org/10.3168/jds.S0022-0302(99)75431-7.

Urrutia, N. L., and K. J. Harvatine. 2017. Acetate dose-dependently stimulates milk fat synthesis in lactating dairy cows. J. Nutr. 147:763-769. https://doi.org/10.3945/jn.116.245001.

Williamson, D. H., J. Mellanby, and H. A. Krebs. 1962. Enzymic determination of $\mathrm{D}(-)$-beta-hydroxybutyric acid and acetoacetic acid in blood. Biochem. J. 82:90-96.

Yu, P. 2010. Plant-based food and feed protein structure changes induced by gene-transformation, heating and bio-ethanol processing: A synchrotron-based molecular structure and nutrition research program. Mol. Nutr. Food Res. 54:1535-1545. https://doi.org/10 $.1002 / \mathrm{mnfr} .201000178$

Yu, P.. Z. Niu, and D. A. Christensen. 2010. Effects of partially replacing barley or corn with raw and micronised CDC SO-I oats on productive performance of lactating dairy cows. Arch. Anim. Nutr. 64:425-436. https://doi.org/10.1080/1745039X.2010.496949.

Yu, G. Q., and P. Yu. 2015. Combining vibrational biomolecular spectroscopy with chemometric techniques for the study of response and sensitivity of molecular structures/functional groups mainly related to lipid biopolymer to various processing applications. Anal. Bioanal. Chem. 407:7245-7253. https://doi.org/10.1007/ s00216-015-8883-Z.

Zhang, X., and P. Yu. 2012. Relationship of carbohydrate molecular spectroscopic features in combined feeds to carbohydrate utilization and availability in ruminants. Spectrochim. Acta A Mol. Biomol. Spectrosc. 92:225-233. https://doi.org/10.1016/j.saa.2012.01 .070 .

Zhong, R. Z., J. G. Li, Y. X. Gao, Z. L. Tan, and G. P. Ren. 2008. Effects of substitution of different levels of steam-flaked corn for finely ground corn on lactation and digestion in early lactation dairy cows. J. Dairy Sci. 91:3931-3937. https://doi.org/10.3168/ jds.2007-0957.

\section{ORCIDS}

Luciana L. Prates (ำ https://orcid.org/0000-0001-8398-6749

Peiqiang Yu ৫ https://orcid.org/0000-0001-8406-464X 